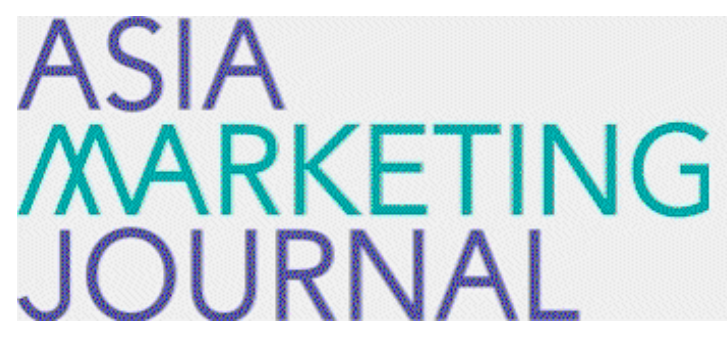

ASIA MARKETING JOURNAL

Volume 13 | Issue 1

Article 1

4-30-2011

\title{
도시 생활의 질(Quality of City Life) 측정 도구의 개발
}

Dong Jin Lee

Grace B. Yu

Follow this and additional works at: https://amj.kma.re.kr/journal

Part of the Marketing Commons

\section{Recommended Citation}

Lee, Dong Jin and Yu, Grace B. (2011) "도시 생활의 질 (Quality of City Life) 측정 도구의 개발," Asia Marketing Journal: Vol. 13 : Iss. 1 , Article 1.

Available at: https://doi.org/10.53728/2765-6500.1275

This Article is brought to you for free and open access by Asia Marketing Journal. It has been accepted for inclusion in Asia Marketing Journal by an authorized editor of Asia Marketing Journal. 


\section{Developing a Subjective Measure of the Quality of City Life (QCL) : The Case of Seoul*}

\section{도시 생활의 질(Quality of City Life) 측정 도구의 개발 : 서울시를 중심으로}

Dong-Jin Lee(이동진)**

Grace B. $\mathrm{Yu}($ 유병희 $) * * *$

Measuring the quality of city life (QCL) is important for city marketing given that QCL influences the city brand image and resident city relationship. Despite its importance, most previous measures of community well being were developed in the context of small towns, and limited attention has been given to a subjective measure of QCL in the context of a large city. This study develops and tests a subjective measure of quality of city life (QCL) in the context of a large metropolitan city. Quality of city life (QCL) refers to the degree of need satisfaction and feelings of happiness one experiences during the course of city life. The results from a survey of 507 residents from 25 major districts in Seoul indicate that the QCL measure has convergent and discriminate validity. The results also indicate that QCL has predictive validity in relation to satisfaction with city services, trust in the city government, word of mouth communication, and a sense of citizen pride. The managerial and policy implications of this study are discussed.

Key words: quality of city life (QCL), satisfaction with city services, trust with the city, word of mouth communications, and sense of pride

* This work was supported by the Korean Research Foundation Grant by the Korean Government (KRF-2010-327-B00228).

** Dong-Jin Lee is a Professor of Marketing at Yonsei University in South Korea

*** Grace B. Yu is a post-doctoral research fellow at Yonsei University in South Korea, Tel.: 82-2-2123-5471, Fax: 82-2-313-5331, E-mail: bienie81@yonsei.ac.kr 


\section{I . Introduction}

The effect of marketing on the overall quality of life or life satisfaction has interested many scholars (Lee et al. 2002, Sirgy, Lee, and Rahtz 2006; Sirgy, Lee, and Rahtz 2008). Studies have found that overall life satisfaction is positively related to satisfaction with specific life domains, including satisfaction with work, satisfaction with family, satisfaction with consumption, and satisfaction with city life, among others (Costa and McCrae 1980; Day 1978, 1987; Diener 1984; Lee and Sirgy 2004; Lee et al. 2002; Leelakulthanit, Day and Walters 1991; Sirgy 2001; Sirgy, Lee, Rahtz 2006).

The relationship between overall life satisfaction and satisfaction with specific life domains can be explained by the spillover theory of life satisfaction (Andrews and Withey 1976; Diener 1984; Sirgy 2001). The spillover theory of life satisfaction can be classified into three sub-theories depending on the direction of spillover. The bottom-up spillover theory of life satisfaction posits that when people are satisfied with a specific life domain, the satisfaction with the specific life domain vertically spills over into overall life satisfaction (Andrews and Withey 1976; Diener 1984). The top-down spillover theory of life satisfaction posits that when people are satisfied with their overall life, this overall positive affective state is likely to influence their level of satisfaction with specific life domains (Diener 1984; Diener and Chan 2011). The bi-directional spillover theory of life satisfaction posits that the relationship between overall life satisfaction and domain satisfaction is bi-directional (Costa and McCrae 1980; Kozma 1997).

The main focus in this study is satisfaction with city life or the quality of city life (QCL). The quality of city life (QCL) is defined as the degree of need satisfaction and feelings of happiness one experiences in the city life domain. The definition is based on the notion of need hierarchy and affect balance in life satisfaction (Diener and Chan 2011; Lucas, Diener, and Suh 1996; McCrae 1980; Yu and Lee 2008).

Measuring the subjective quality of city life (QCL) is important given that QCL is an important factor that affects people's city brand image and their relationship with the city, as defined by their satisfaction, trust, and loyalty towards the city (House 1986; Kotler, Jutasripitak and Maesincee 1997; Paddison 1993; Rogerson 1999; Senlier, Yildiz and Atikas 2009; Vieto 2007). While there have been several approaches to measure the quality of

\section{2 한국마케팅저널 제13권 제1호 2011년 4월}


community life in the context of small towns (Sirgy, Gao and Young 2008; Sirgy, Widgery, Lee and Yu 2010), limited attention has been given to the development of a subjective measure of QCL in the context of a large city.

The main objective of this study is, therefore, to develop and test a subjective measure of quality of city life (QCL) in the context of a large city. In detail, this study has the following specific objectives. First, the study will develop and test a measure of QCL based on the theory of need hierarchy and affect balance. Unlike previous studies that measured community well-being using need satisfaction only (e.g., Lee et al. 2002; Pilcher 1998; Sam 2001; Sirgy et al. 2008), this study will conceptualize QCL as having both a cognitive dimension (need satisfaction) and affective dimension (feeling of happiness). Second, this study will develop a measure of QCL in the context of a large city. This is done with data from the residents of Seoul, a large metropolitan city. To the best of our knowledge, this is the first study that measures QCL in terms of need satisfaction and feelings of happiness in the context of a very large city. Third, this study will examine the effects of QCL on a set of outcomes, including satisfaction with city services, trust of the city, a sense of pride as a citizen, and positive word of mouth intentions.

The development of a QCL measure in the context of a large city will facilitate a stream of future studies on the quality of city life. The study findings will also help policymakers and city marketers to develop city marketing strategies and allocate resources in ways that effectively enhance the QCL. An enhanced QCL will lead to positive word-of-mouth communications among citizens which will increase citizen pride, thereby enhancing the city's brand image.

The paper proceeds as follows. First, the conceptual definitions and dimensions of QCL are discussed. Next, we present a set of hypotheses related to the outcomes of QCL, after which we explain the survey method, the construct validity of the QCL measure, and the predictive (nomological) validity of the QCL measure. The paper is concluded with managerial and theoretical implications along with future research directions.

\section{Conceptual Development}

\subsection{Overall Quality of Life (QOL) vs. Quality of City Life (QCL)}

In general, the overall quality of life 
(QOL) refers to the degree to which an individual judges the overall quality of his or her life in a favorable way (Veenhoven 1984). An example measure of the overall QOL is life satisfaction (Diener 1984).

Overall QOL is positively related to satisfaction with specific life domains such as satisfaction with the work life domain, satisfaction with the family life domain, satisfaction with the economic life domain, and satisfaction with the city life domain, among others. The quality of city life (QCL) is domain-specific life satisfaction resulting from the degree of need satisfaction and feelings of happiness one experiences in the city life domain.

The relationship between the overall QOL and the domain-specific QCL can be explained using the spillover theory of life satisfaction (Diener 1984; Sirgy 2001). The spillover theory of life satisfaction explains affect transfer between satisfaction with a specific life domain (e.g., QCL) and overall life satisfaction (e.g., QOL). The spillover theory of life satisfaction can further be classified into three theories: the bottom-up spillover theory, the top-down spillover theory, and the bi-directional spillover theory of life satisfaction.

The bottom-up spillover theory of life satisfaction posits that positive and negative affect from specific life domains spills over into overall life satisfaction (Diener 1984; Lee at al. 2002). In other words, this theory posits that people's concrete life experiences in their city (QCL) will vertically spill over into their overall QOL.

The top-down spillover theory of life satisfaction posits that a high QOL has a positive influence on QCL. Specifically, a person with a high QOL is likely to also feel positive about the quality of specific life domains including QCL (Diener 1984; Diener and Chan 2011). The top-down spillover theory posits that when people's QOL is high, they are likely to feel positive about QCL too.

The bi-directional spillover theory of life satisfaction posits that the relationship between overall life satisfaction (QOL) and domain-specific satisfaction (e.g., QCL) is bi-directional. The bi-directional model is an integrative model that combines top-down and bottom-up influences. Studies have found that the bi-directional model is more predictive than both the top-down and bottom-up models (Brief et al. 1993; Costa and McCrae 1980; Headey, Veenhoven, and Wearing 1991; Kozma 1997).

It should be noted that our main focus in this study is QCL, not overall QOL. We will first measure the overall QCL based on the

\section{4 한국마케팅저널 제13권 제1호 2011년 4월}


notions of need satisfaction and affect balance. We then will test the relationship between the overall QCL and facet-specific satisfactions within the city life domain based on the theory of top-down spillover within the city life domain. This is based on the top- down spillover theory in that QCL affects facet specific satisfactions (Headey, Veenhoven, and Wearing 1991).

\subsection{Subjective Measure of QCL}

Our measure of QCL in this study has the following characteristics. First, we focus on the subjective measure of QCL (Sirgy and Lee 2006). While QCL can also be conceptualized in terms of many objective indicators, this study focuses on a subjective evaluation of QCL.

Second, we focus on a subjective measure of overall QCL. That is, instead of measuring situation-specific satisfaction (Grzeskowiak et al. 2007; Sirgy et al. 2008, 2010), we focus on a subjective measure of overall QCL. In other words, instead of measuring satisfaction with specific events in their city life, our QCL measure focuses on measuring overall satisfaction with the city life domain.

Third, our subjective measure of overall QCL includes both cognitive measures (e.g., need satisfaction in city life) and affective measures (e.g., experience of positive affect in city life (Argyle 1996; Veenhoven 1984; Diener and Chan 2011). Previous measures of community well-being mostly focused on the cognitive evaluations (Grzeskowiak et al. 2007; Sirgy et al. 2008, 2010). However, the measure of QCL in this study will tap into overall need satisfaction in city life as well as experiences of positive affect in city life.

\subsection{Dimensions of QCL}

The quality of city life (QCL) is defined as the degree of need satisfaction and feelings of happiness experienced as one experiences city life. QCL often vertically spills over into one's overall quality of life (Andrews and Withey 1976). In previous studies, the overall quality of life was conceptualized in terms of two components: the cognitive component (i.e., satisfaction with life) and the affective component (i.e., the presence of positive affect and the absence of negative affect) (Argyle 1996; Diener, Smith, and Fujita 1995). Similarly, QCL in this study is conceptualized as having a cognitive component and an affective component (Argyle 1996; Cha 2003; Pilcher 1998; Sam 2000).

The cognitive dimension of QCL refers to the global assessment of one's city life, 
in terms of need satisfaction, according to one's chosen criteria (Diener and Emmons 1984; Sirgy 1986). Cognitive QCL is related to satisfaction of various needs, including health and safety needs, economic and family needs, social needs, self-esteem needs, self-actualization needs, knowledge needs, and aesthetics needs (Kamp et al. 2003; Stimson et al. 1999; Wish 1986). These need dimensions are based on both lower-order and higher-order needs in the need hierarchy (Lee et al. 2002; Sirgy, Gao, and Young 2008)

The affective dimension of $\mathrm{QCL}$ reflects the difference between the positive affect (PA) and negative affect (NA) experienced during the course of city life (cf. Bradburn 1969; Diener, Smith, and Fujita 1995). PA includes feelings such as enthusiasm, interest, determination, excitement, inspiration, alertness, strength, pride, and attentiveness. NA includes feelings such as fear, dismay, distress, nervousness, shame, guilt, irritability, and hostility (Bradburn 1969; Diener, Smith, and Fujita 1995; Plutchick 2003). Previous studies have shown that the frequency of emotional experiences is more important than the intensity of the emotional experience in evaluations of the overall quality of life (Diener, Sandvik, and Pavot 1991). Studies have shown NA, PA, and life satisfaction are conceptually distinct and empirically separable (Diener and Chan 2011; Lucas, Diener, and Suh 1996; Yu and Lee 2008).

The affective component and cognitive component of $\mathrm{QCL}$ are related. Because affective QCL and cognitive QCL are related to each other, studies have conceptualized QCL as a composite of cognitive and affective components. Specifically, QCL is defined as the degree to which citizens' needs are satisfied within their city life domain and the degree to which citizens experience happiness in their city life (Lucas, Diener, and Suh 1996; Yu and Lee 2008).

\subsection{Consequences of QCL}

What are consequences of QCL? We conceptualize four outcomes of QCL, including satisfaction with city services, trust of the city, a sense of pride, and positive word of mouth communication. All of these factors are related to the quality of the relationship (satisfaction, trust, and loyalty) between residents and the city.

\section{QCL and Satisfaction with the City} Services: People characterized by a high QCL are likely to be satisfied with their city services. Through the attribution process and the notion of top-down

\section{6 한국마케팅저널 제13권 제1호 2011년 4월}


spillover, these people are also likely to feel positive about the city services they experience (Inglehart and Rabier 1986; Sirgy 2001).

It should be noted that satisfaction with city services and QCL are conceptually distinct in the following ways. First, citizen satisfaction is a micro concept that is transaction-specific while QCL is a macro concept resulting from overall evaluations of their experiences with city life over an extended period of time (Rahtz, Sirgy, and Lee 2004; Sirgy et al. 2010). Second, citizen satisfaction is transient and temporary while QCL is a rather stable concept (Kozma 1997). For example, QCL is not significantly influenced by an incidental experience of service failure by the city (Lee et al. 2002). Third, citizen satisfaction is an affective response to city services while QCL has a higher order construct composed of both cognitive and affective evaluations (Lucas, Diener, and Suh 1996; Yu and Lee 2008).

This study posits that QCL has a positive influence on satisfaction with city services. As QCL is a macro concept overall that covers a wide variety of experiences in city life, one can argue that a high QCL is likely to lead to high satisfaction with city services through the attribution process. When QOL is high, people are likely to feel that the services of their city are good as well (Dagger and Sweeny 2009; Ferrans and Powers 1992; Kelly 2003). Through the attribution process and top-down spillover of positive affect, we posit that when people's perception of the overall QCL is high, they are also likely to feel positive about city services (Sirgy, Gao, and Young 2008; Van Ryzin et al. 2004). Based on this discussion, the following hypothesis is proposed:

H1: QCL has a positive influence on satisfaction with the services of the city

QCL and Trust with the City: According to the institutional theory of trust (Hudson 2006; Inglehart 1997; North 1990; Sztomka 1999), trust of a city is formed by evaluations of the city performance.

We conceptualize citizen trust as the degree to which citizens believe that the city government is competent, benevolent, and righteous (Barney and Hansen 1994; Lane 1998; Shapiro, Sheppard and Cheraskin 1992; Zucker 1986). The first dimension of trust is integrity. The city government will be considered as having integrity if the people believe that the city adheres to a common set of principles that 
the citizens find acceptable (Doney and Cannon 1997; Mayer, Davis, and Shoorman 1995). Integrity is based on, and perceptions of justice. When people consider a city government to have a high level of integrity, they are likely to be less anxious, especially in times of uncertainty (Doney and Cannon 1997).

The second dimension of trust is competence. The city will be considered competent if people believe that the city officials have expertise in their chosen field (Mayer, Davis, and Shoorman 1995). When people believe that their city is competent in providing services in a reliable and predictable manner, they will have greater trust of their city government (cf. Szymanski and Heanrd 2001).

The third dimension of trust is benevolence. The city will be considered as being benevolent when the city presents a caring attitude for the well-being of the people by providing sufficient support, assuming fiduciary responsibility, and expressing consideration for the residents (Atuahene-Gima and Li 2002; Selnes and G $x^{\top}$ nhaug 2000; Sirdeshmukh, Singh, and Sabol 2002).

People with a high QCL are likely to perceive that a city effectively performs its tasks with integrity and benevolence (Ekici and Peterson 2009; Inglehart 1999).
Moreover, these people are likely to believe that the city government can be relied on with confidence to meet their responsibilities in a fiduciary manner (Doney and Cannon 1997; Mogran and Hunt 1994). Based on this discussion, it can be hypothesized that:

H2: QCL has a positive influence on trust of a city government.

\section{QCL and Positive Word-of-Mouth}

Communication: Word-of-mouth communication is a type of interpersonal communication among the members of a reference group (Assel 2004). Word-of-mouth communication includes referral behaviors in which people make positive or negative comments regarding a product based on their experiences with that product. Word-ofmouth communication is perceived to be trustworthy by the general public, as it is not directly related to the consumer's self-interest (Anderson et al. 1994).

This study posits that QCL has a positive impact on people's word-of-mouth communications regarding their city life. When city residents are happy with their city life, they tend to be emotionally attached and committed to the city (Hennig-Thurau et al. 2001; Paddison 1993), thereby creating positive word-of- 
mouth communications regarding their city life (Hall and Stamp 2003; Hennig-Thurau et al. 2001; Verhoef, Franses, and Hoekstra 2002). When city residents are satisfied with their city life and when they are happy with it, they are likely to say many positive things about their experiences in the city to their friends and family (Tilson and Stacks 1997; Verhoef, Franses, and Hoekstra 2002). Based on this discussion, the following hypothesis is proposed:

H3: QCL has a positive influence on positive word-of-mouth communications.

\section{QCL and Sense of Pride: When people} have a high QCL, they are more likely to identify with their city (Hennig-Thurau et al. 2001). When the QCL is high, people are likely to perceive the city as attractive and thus become motivated to see the image of their city as having a greater degree of semblance with their own self-image (Bhattacharya and Sen 2003; Brewer 1991; Tajfel and Turner 1986). When citizens identify their self-image as matching the image of their city, the city image becomes an expression of their self image, and people gain a sense of pride in their city. In contrast, in the case of a low QCL, people are less likely to have a sense of pride about their city (Avraham 2004). Based on this discussion, the following is proposed:

H4: QCL has a positive influence on the sense of pride as a citizen.

\section{Methods}

\subsection{Data Collection Procedure}

The measurement items for the constructs in this study were generated through a literature review, in depth interviews with industry experts, and a pilot test. Based on previous studies, items related to QCL were generated. Content validity as this pertains to the measurement items were evaluated by three academic experts. Subsequently, a total of 30 in-depth interviews were conducted with city officials, public relations experts, and marketing research experts. Following this, we conducted a pre-test with 80 university students who live in Seoul.

The main survey involved a sample of 507 adult residents who were interviewed in shopping malls or shopping centers in 25 major areas in the city of Seoul, Korea. Seoul was chosen because it is clearly 
representative of a large city. In addition, the citizens of Seoul have recently begun to care more about the quality of city life, and few studies have been conducted in a large city within a newly developed country. Data was collected from 25 different districts within Seoul to maximize the variance in the responses. The demographic profile of the pooled sample is as follows: age: $24 \%$ (20s), 25\% (30s), $29 \%$ (40s), and 23\% (50s and above); employment status: $68 \%$ full-time, $21 \%$ part-time, and $11 \%$ unemployed; gender: $49 \%$ male, $51 \%$ female. In terms of education, a majority of the respondents $(73.2 \%)$ reported having at least a bachelor's degree (Table 1).

〈Table 1〉 Sample Characteristics ( $N=507)$

\begin{tabular}{|l|l|}
\hline Variables & $(\%)$ \\
\hline Gender & \\
\hline Male & 49.1 \\
\hline Female & 50.9 \\
\hline Age & \\
\hline 29 or under & 24.1 \\
\hline 30-39 & 24.7 \\
\hline 40-49 & 29.0 \\
\hline 50 or more & 22.3 \\
\hline Education & \\
\hline High-school graduates & 26.8 \\
\hline University graduates & 73.2 \\
\hline
\end{tabular}

\subsection{Measures Used in This Study}

In this study, items dealing with the relationship between QCL and citizens' attitudes toward their city government were generated based on existing literature. Several items had to be deleted due to a lack of content validity, low internal consistency, or high cross loadings.

Quality of City Life: QCL was defined as the degree to which citizens' needs are met within their city life (cognitive aspect) and the degree to which citizens experience positive affect or happiness as they live in their city (affective aspect). Items that measure the affective aspects of QCL include: 1) I think this city is a good place to live, and 2) I am happy living in this city, and the items that tap into the cognitive aspect of QCL include 3) The quality of life in this city is high, and 4) This city satisfies the various needs of its citizens ( $1=$ strongly disagree, $5=$ strongly agree).

\section{Satisfaction with the City Services:} Citizens' satisfaction with city services is defined as citizens' affective response towards the city resulting from an appraisal of the services of the city (Anderson and Narus 1984). Items that measure satisfaction with city services include: 1) overall, I am satisfied with the city's public services, 2) The service performance of 
the city meets my expectations as a citizen, 3) The city's public services satisfy its citizens (1=strongly disagree, 5= strongly agree).

Trust of the City Government: Citizens' trust in their city government is defined as the degree to which citizens believe that the city government is competent, benevolent, and righteous (integrity) (Barney and Hansen 1994; Lane 1998; Shapiro et al. 1992; Zucker 1986). Items that measure this construct include: 1) I trust the city government in general (overall trustworthiness perception), 2) I think the city government is successful in delivering an image of trustworthiness (competence), 3) I think the city government consistently keeps its promises (integrity), and 4) I think that the city government takes good care of its citizens (benevolence) (1=strongly disagree, 5= strongly agree).

\section{Positive Word-of-Mouth Communication:}

Positive word-of-mouth communication is defined as the degree to which a citizen voluntarily engages in interpersonal communication with other citizens regarding the positive aspects of the city (Assel 2004). Items used to measure positive word-of-mouth communication include: 1) I usually talk about the positive aspects of the city, and 2) I often say this city is a good place to live (1=strongly disagree, 5= strongly agree).

Pride as a Citizen: Pride as a citizen is defined as the degree to which a person feels proud to be a citizen of the city. Items that measure citizen pride include: 1) I have a strong sense of pride as a citizen, and 2) I am proud of being a citizen (1=strongly disagree, $5=$ strongly agree).

\subsection{Measurement Model}

To ensure the reliability and unidimensionality of the construct measures, confirmatory factor analyses were performed within the construct in order to purify the items. All measurement items are unidimensional, and the model provided a good fit to the data. Next, confirmatory factor analyses were conducted across the construct. The fit indices for the confirmatory factor analysis across the construct indicated that the measurement model provided a good fit to the data $\left(\mathrm{X}^{2}{ }_{(80)}=303.56\right.$, RMSEA $=0.07$, $\mathrm{NFI}=0.95, \mathrm{CFI}=0.96, \mathrm{RMR}=0.03, \mathrm{GFI}=$ 0.92). The results of the reliability and validity tests are summarized in Table 2-1 and 2-2. 
$\langle$ Table 2-1〉 Reliability and Validity Assessment of the Theoretical Construct Measures

\begin{tabular}{lc}
\hline Construct & Standardized Loadings \\
\hline Satisfaction with City & Services $(a=0.90, \rho=0.90)$ \\
1. sat 1 & $0.827(22.344)^{\mathrm{a}}$ \\
2. sat 2 & $0.869(24.161)$ \\
3. sat 3 & $0.888(25.061)$
\end{tabular}

Trust on the City Government $(a=0.92, \rho=0.89)$

1. trust 1

$0.865(24.128)$

2. trust 2

$0.868(24.258)$

3. trust 3

$0.838(22.922)$

4. trust 4

0.845 (23.229)

Quality of City Life $(a=0.87, \rho=0.87)$
1. QCL 1
$0.810(21.387)$
2. QCL 2
$0.829(22.133)$
3. QCL 3
$0.773(19.966)$
4. QCL 4
$0.724(18.184)$

Pride as a citizen $(a=0.88, \rho=0.88)$

1. pride 1

$0.885(24.300)$

2. pride 2

$0.890(24.523)$

Word-of-Mouth $(a=0.77, \rho=0.76)$

1. wom 1

$0.764(19.390)$

2. wom 2

$0.808(20.868)$

Fit indices:

$\chi^{2}(p-$ value $)=303.558(.00), d f=80 ; \mathrm{GFI}=0.923 ; \mathrm{CFI}=0.963 ; \mathrm{NFI}=0.950 ;$ RMSEA $=0.076$

a $a$ = Cronbach's Alpha; $\rho=$ composite reliability

$\langle$ Table 2-2〉 Test of Discriminant Validity

\begin{tabular}{|l|c|c|c|c|c|c|}
\hline & \multicolumn{5}{|c|}{ Phi square } & \\
\hline & $\mathrm{a}$ & $\mathrm{b}$ & $\mathrm{c}$ & $\mathrm{d}$ & $\mathrm{e}$ & AVE \\
\hline Satisfaction with City Services & 1.000 & & & & & 0.862 \\
\hline Trust of the City Government & 0.854 & 1.000 & & & & 0.857 \\
\hline Quality of City Life & 0.373 & 0.630 & 1.000 & & & 0.785 \\
\hline Pride as a Citizen & 0.566 & 0.784 & 0.808 & 1.000 & & 0.888 \\
\hline Word-of-Mouth & 0.402 & 0.665 & 0.664 & 0.839 & 1.000 & 0.786 \\
\hline
\end{tabular}

* The average variance extracted by the underlying constructs is larger than the shared variance (Phi square) except for pride as a citizen and WOM.

The results of the confirmatory factor from 0.72 to 0.89 ) with no high cross analysis across the constructs indicate that all items are significantly loaded to their theorized factors (factor loadings ranging loadings. The results provide support for the convergent validity of measurement items (Anderson and Gerbing 1988). Next, 
the reliability of all measures was assessed by computing Cronbach's Alpha, composite reliability and the average extracted variance. All of these coefficients were above the accepted standard of 0.70 .

Discriminant validity was assessed using a variety of methods. First, the confidence interval of latent factor correlations was examined, and none of the 95\% confidence intervals of the latent factor correlation matrix had a value of 1.0. Second, a series of Chi-square difference tests were conducted for each pair of constructs between the constrained model and the unconstrained model. In all cases, the unconstrained model provided a significantly better fit to the data than the constrained model $(p<0.01)$. Third, the shared variances between all possible pairs of constructs were found to be significantly lower than the average variance extracted for the individual construct except for word-of-mouth intention and pride as a citizen (Fornell and Larcker 1981). All of these results provide evidence of the discriminant validity of the measures.

\subsection{Hypotheses Testing}

The proposed conceptual model (Figure 1) was tested using structural equation modeling. The correlation matrix for the constructs used in this study is shown in Table 3.

Test of the Main Conceptual Model: The results of the structural relationship of the conceptual model are shown in Table 4.

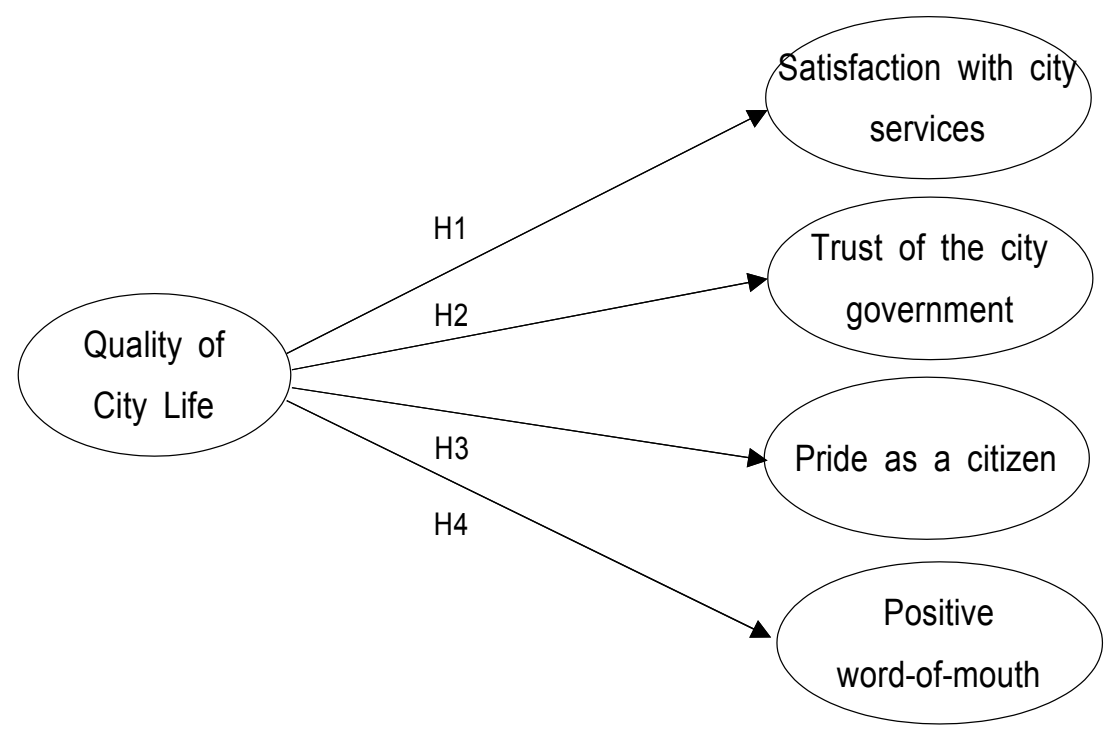

〈Figure 1〉 The Conceptual Model 
$\langle$ Table 3〉 Correlation Matrix

\begin{tabular}{|l|c|c|c|c|c|}
\hline & a & b & c & d & e \\
\hline Satisfaction with City Services & 1.00 & & & & \\
\hline Trust of the City Government & 0.84 & 1.00 & & & \\
\hline Quality of City Life & 0.56 & 0.60 & 1.00 & & \\
\hline Pride as a Citizen & 0.55 & 0.56 & 0.71 & 1.00 & \\
\hline Word-of-Mouth & 0.63 & 0.66 & 0.75 & 0.74 & 1.00 \\
\hline & & & & & \\
Mean & 2.78 & 2.79 & 2.98 & 2.96 & 2.92 \\
S.D. & 0.84 & 0.84 & 0.79 & 0.88 & 0.84 \\
\hline
\end{tabular}

$\left\langle\right.$ Table 4〉 Test of the Relationships for the Conceptual Model ${ }^{a}$

\begin{tabular}{|l|l|}
\hline Structural Relationships & Standardized Estimates $(t$-value $)$ \\
\hline H1: Quality of City Life $\rightarrow$ Satisfaction with City Services & $0.755 * *(15.980)$ \\
\hline H2: Quality of City Life $\rightarrow$ Trust of the City Government & $0.779 * *(17.314)$ \\
\hline H3: Quality of City Life $\rightarrow$ Positive Word-of-Mouth & $0.986 * *(19.230)$ \\
\hline H4: Quality of City Life $\rightarrow$ Pride as a Citizen & $0.857 * *(19.752)$ \\
\hline $\mathrm{X}^{2}$ (86) $=683.940$, RMSEA $=0.116$, NFI $=0.888$, CFI $=0.901$, SRMR $=0.091$, GFI $=0.850$ \\
\hline
\end{tabular}

a. $* *$ Significant at the 0.05 level.

The results indicate that the conceptual model provided a good fit to the data $\left(x^{2}\right.$ $(86)=683.940$, RMSEA $=0.116, \quad \mathrm{NFI}=$ 0.888, $\mathrm{CFI}=0.901, \mathrm{SRMR}=0.091, \mathrm{GFI}=$ 0.850).

H1 posits that QCL has a positive predictive influence on satisfaction with city services. The results indicate that QCL does indeed have a positive influence on satisfaction with city services (estimate = 0.755, $\mathrm{p}<0.05)$, supporting H1.

H2 states that QCL has a positive predictive influence on trust of the city government. The result indicate that QCL has a positive influence on trust of the city government (estimate $=0.779, \mathrm{p}<0.05$ )
Thus, the results support H2.

H3 holds that QCL has a positive predictive influence on positive word-of-mouth communications. The results indicate that QCL does have a positive influence on positive word-of-mouth communications, supporting H3 (estimate $=0.986, \mathrm{p}<0.05)$.

$\mathrm{H} 4$ posits that $\mathrm{QCL}$ has a positive predictive influence on citizens' pride in their city. The results indicate that QCL does have a positive influence on the citizens' pride in their city (estimate = 0.857, $\mathrm{p}<0.05)$, supporting H4.

Test of Alternative Models: One can 
argue that satisfaction with city services mediates the relationship between QCL and trust of the city government (QCLSatisfaction-Trust), as trust is formed based on cumulative satisfaction experiences (Mayer, Davis, and Shoorman 1995; Szymanski and Heanrd 2001). We tested this possibility, and the results indicate that QCL does indeed have a positive influence on citizen trust fully mediated by citizens' satisfaction with their city's services ( $t=$ 12.489, $\mathrm{p}<$.050) (Table 5-1). The result of a Sobel test ${ }^{2}$ (Baron and Kenny 1986; MacKinnon, Warsi, and Dwyer 1995) also confirmed that QCL has a positive influence on trust of the city mediated by satisfaction with city services.

One can also argue that QCL is likely to

$\left\langle\right.$ Table 5-1〉 Test of the Relationship in the Alternative Model (Satisfaction as a Mediator) ${ }^{\text {a }}$

\begin{tabular}{|l|c|}
\hline \multicolumn{1}{|c|}{ Structural Relationships } & $\begin{array}{c}\text { Standardized Estimates } \\
(t \text {-value })\end{array}$ \\
\hline H1: Quality of City Life $\rightarrow$ Satisfaction with City Services & $0.692 * *(14.688)$ \\
\hline H2: Quality of City Life $\rightarrow$ Trust of the City Government & $0.156 * * \quad(3.981)$ \\
\hline H3: Satisfaction with City Services $\rightarrow$ Trust with City Government & $0.818 * *(16.524)$ \\
\hline H4: Quality of City Life $\rightarrow$ Positive Word-of-Mouth & $0.977 * *(18.506)$ \\
\hline H5: Quality of City Life $\rightarrow$ Pride as a Citizen & $0.863 * *(19.943)$ \\
\hline $\mathrm{x}^{2}{ }_{(85)}=363.499$, RMSEA $=0.817, \mathrm{NFI}=0.941, \mathrm{CFI}=0.954$, SRMR $=0.043$, GFI $=0.911$ \\
\hline
\end{tabular}
a. ** Significant at the 0.05 level.

〈Table 5-2〉 Sobel Test of Mediation Effect for the Alternative Model

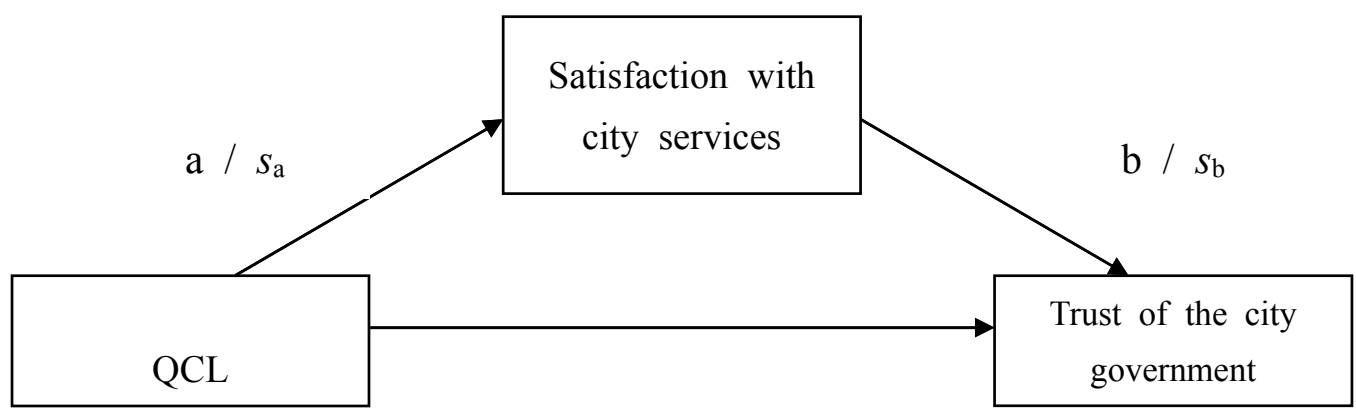

\begin{tabular}{|c|c|c|c|}
\hline $\mathrm{a} / \mathrm{s}_{\mathrm{a}}$ & $\mathrm{b} / \mathrm{sb}_{\mathrm{b}}$ & Test statistic & $\mathrm{p}$-value \\
\hline $0.522(0.037)$ & $0.752(0.028)$ & $12.489 * *$ & 0.000 \\
\hline
\end{tabular}

$a=$ raw (unstandardized) regression coefficient for the association between the IV and the mediator.

$S_{\mathrm{a}}=$ standard error of $a$.

$b=$ raw coefficient for the association between the mediator and the DV (when the IV is also

a predictor of the DV).

$\mathrm{S}_{\mathrm{b}}=$ standard error of $b$

** significant at $p<0.05$ 
$\left\langle\right.$ Table 6) Test of the Conceptual Model with Income as a Moderatora ${ }^{\text {a }}$

\begin{tabular}{|l|c|c|}
\hline \multicolumn{1}{|c|}{ Structural Relationship } & \begin{tabular}{c} 
Low $\begin{array}{c}\text { Income Group } \\
(\mathrm{n}=339)\end{array}$ \\
\cline { 2 - 3 }
\end{tabular} & $\begin{array}{c}\text { Higher Income Group } \\
(\mathrm{n}=168)\end{array}$ \\
\hline H1: Quality of City Life $\rightarrow$ Satisfaction with City Services & $0.546 * *(10.348)$ & $0.574 * *(10.972)$ \\
\hline H2: Quality of City Life $\rightarrow$ Trust of the City Government & $0.579 * *(11.302)$ & $0.606 * *(11.904)$ \\
\hline H3: Quality of City Life $\rightarrow$ Pride as a Citizen & $0.683 * *(15.073)$ & $0.720 * *(15.994)$ \\
\hline H4: Quality of City Life $\rightarrow$ Positive Word of Mouth & $0.774 * *(18.344)$ & $0.725 * *(17.308)$ \\
\hline $\mathrm{X}^{2}{ }_{(16)}=635.587$, RMSEA $=0.379, \mathrm{NFI}=0.644, \mathrm{CFI}=0.649$, SRMR $=0.163, \mathrm{GFI}=0.680$ \\
\hline
\end{tabular}

a. ** Significant at the 0.05 level.

* Higher income group: Households with monthly income greater than 4,000,000 KRW.

have a greater effect on satisfaction in a low-income group than in a high-income group. This is due to the possibility that low-income residents are heavily involved with city services (cf. Sirgy, Rahtz, and Lee 2004). We tested this possibility by formally introducing income as a moderator in the conceptual model. The results indicate that, regardless of income level, QCL has a positive influence on satisfaction with city services, trust of the city government, citizen pride, and positive word of mouth intentions (Table 6). That is, the results show that household income was not a significant moderator in the model.

\section{Discussion}

\subsection{Summary of Results}

This study developed a measure of QCL in the context of a large city. The survey results from 507 residents in Seoul indicate that the subjective measure of QCL has adequate convergent and discriminant validity. The results also indicate that the subjective measure of QCL has an adequate level of predictive validity as QCL influences the city-resident relationship quality, including satisfaction, trust, sense of pride, and word of mouth communications. While not hypothesized, the results also indicate that citizen satisfaction with city services mediates the relationship between QCL and trust of the city.

\subsection{Theoretical and Managerial Implications}

This study has several theoretical implications. First, many community well-being measures are based on the theory of the bottom-up spillover of 
resident satisfaction. Here, we found that QCL has a positive influence on people's satisfaction with city services in a top-down manner. This implies that enhancing the overall QCL should take priority when formulating the marketing strategies and public policies of a city. The contribution to overall QCL can be an important criterion for guiding the allocation of resources and efforts across various city services.

Second, this study found that citizens with high QCL values are likely to have a sense of pride as a citizen. Citizens' sense of pride and identification with the city are important for the establishment of a positive long-term relationship between the city and its citizens. High QCL values can increase the support of citizens and their long-term commitment to the city.

Third, this study found that QCL has a positive influence on citizens' word-ofmouth communications. While QCL is likely to encompass one's overall quality of life, the results of this study suggest that QCL engenders positive word-of-mouth, indicating that enhancing QCL is an important means of promoting a positive city reputation and city brand image through word-of-mouth communications. City marketers should also promote QCL, as this will lead to positive word-of-mouth communication among citizens.

\subsection{Limitations and Future Studies}

There are several limitations to this study. First, this study is conducted within the context of one city: Seoul, Korea. Future studies should examine the conceptual model of this study in different contexts so as to establish external validity. Future study can test the model in a cross-cultural context.

Second, this study found that QCL has an influence on satisfaction with city services and trust through the attribution process and the theory of top-down spillover. Yet, one can argue that satisfaction and trust vertically spill over into QCL in a bottom up manner (e.g., Dagger and Sweeney 2006). Future study should identify the conditions under which bottom-up vs. top-down spillover occurs in the context of QCL and satisfaction with specific services.

Third, the perception of QCL is influenced by many individual and personality factors. The overall QCL of residents has been found to be positively influenced by optimism, self-esteem, and feelings of achievement (Chow 2005; Emmons and Diener 1986; Sam 2001; Schmuck, Kasser, and Van Ryan 2000). 
Future studies should incorporate these individual factors into a model of QCL.

Fourth, QCL can be defined in terms of subjective indicators as well as objective indicators (Kamp et al. 2003; Yuan, Yuen, and Low 1999); however, this study focused on a subjective measure of QCL. Future studies should examine the interrelationships between the objective and subjective measures of QCL. This study used the overall measure of the quality of city life. Future study should examine various dimensions of QCL (various dimensions of needs satisfaction and feelings of happiness) and the inter-relationships among the dimensions.

Fifth, this study focused on QCL at a single point in time. People's perception of QCL changes over time. Future studies should examine whether and how QCL changes over time through a longitudinal study. This study also assumes that people's perception of the city environment affects people's QCL. Happy citizens can potentially enhance their QCL by improving their society (Veenhoven 2009). Future studies should examine the dynamic nature between happy citizens and QCL over time.

Despite these limitations, this is the first study that formally tests the effect of citizens' trust of the city on QCL. It is hoped that this study motivates future research on the quality of city life.

\section{Appendix: Measurement Items}

\section{Satisfaction with City Services}

1. Overall, I am satisfied with the city's public services.

2. The service performance of the city meets my expectations as a citizen.

3. The city's public services satisfy its citizens.

\section{Trust with City Government}

1. I trust the city government in general.

2. I think the city government is successful in delivering an image of trustworthiness.

3. I think the city government consistently keeps its promises.

4. I think that the city government takes good care of its citizens.

\section{Pride as a citizen}

1. I have a strong sense of pride as a citizen.

2. I am proud of being a citizen.

Word-of-Mouth

1. I usually talk about the positive aspects regarding the city. 
2. I often say that this city is a good place to live.

\section{Quality of City Life (QCL)}

1. I think this city is a good place to live.

2. I am happy living in this city.

3. The quality of life in this city is high.

4. This city satisfies the various needs of its citizens.

〈논문 접수일: 2010. 07. 16〉 <게재 확정일: 2011. 04. 14>

\section{References}

Anderson, J.C. and D.W. Gerbing (1988), "Structural Equation Modeling in Practice: A Review and Recommendation of Two-Step Approach," Psychological Bulletin, 103(3), 411-423.

Anderson, E. W., C. Fornell, and D. Lehman (1994), "Customer Satisfaction, Market Share, and Profitability: Findings from Sweden," Journal of Marketing, 58, 53-66.

Andrews, F. M. and S. B. Withey (1976),

Social Indicators of Well-Being: America's Perception of Quality of Life,

Plenum Press: New York.

Argyle, M. (1996), Subjective Well Being, in A. Offer (Ed), Pursuit of the Quality of Life, Oxford University Press: Oxford, 18-45.

Assael, H. (2004), Consumer Behavior, A Strategic Approach (Houghton Mifflin, New York).

Atuahene-Gima, K. and H. Li (2002), "When Does Trust Matter? Antecedents and Contingent Effects of Supervisee Trust on Performance in Selling New Products in China and the United States", Journal of Marketing, 66(3), 61-81.

Avraham, E. (2004) "Media Strategies for Improving an Unfavorable City Image," Cities 21(6), 471-479.

Barney, J.B. and M. H. Hansen (1994), "Trust Worthiness: Can it be a Source of Competitive Advantage?" Strategic Management Journal, 15(2), 175-203.

Baron, R. M. and D.A. Kenny (1986), "The Moderator-Mediator Variable Distinction in Social Psychological Research: Conceptual, Strategic, and Statistical Considerations," Journal of Personality and Social PSychology, 51, 1173-1182.

Bhattacharya C. B. and S. Sen (2003), "Consumer-Company Identification: A Framework for Understanding Customer's Relationships with Companies," Journal of Marketing, 67 (April), 76-88. 
Brandburn, M. (1969), The Structure of Psychological Well being, Adline: Chicago.

Brewer, M.B. (1991), “The Social Self: On Being the Same and Different at the Same Time," Personality and Social Psychology Bulletin, 17(5), 475-482.

Brief, A. P., A. H. Butcher, J. M. George, and K. E. Link (1993),"Integrating Bottom-up and Top-Down Theories of Subjective Well Being: The Case of Health," Journal of Personality and Social Psychology, 64 (4), 646-653.

Cha, K.H. (2003), "Subjective Well-Being among College Students," Social Indicators Research, 62, 455-477.

Chow, H. P. H. (2005), "Life Satisfaction among University Students in a Canadian Prairie City: A Multivariate Analysis," Social Indicators Research, 70, 139-150.

Costa, P. T. and R. R. McCrae (1980),"Influence of Extraversion and Neuroticism on Subjective Well Being: Happy and Unhappy People," Journal of Personality and Social Psychology, 38, 668-678.

Dagger, T.S. and J.C. Sweeney (2006), "The Effect of Service Evaluations on Behavioral Intentions and Quality of Life," Journal of Services Research, 9 (1), 3-18.
Day, R.L. (1978), "Beyond Social Indicators: Quality of Life at the Individual Level," In Marketing and the Quality of Life, F. D. Reynolds and H. C. Barksdale (Eds), 11-18. Chicago: American Marketing Association.

Day, R.L. (1987) "Relationship between Life Satisfaction and Consumer Satisfaction," In Marketing and Quality of Life Interface, A.C. Samli (Ed), 289-311. Westport, CT: Greenwood.

Diener, Ed. (1984), "Subjective Well Being," Psychological Bulletin, 95, 542-575.

Diener, E., and M. Y. Chan (2011), "Happy People Live Longer: Subjective Well-being Contributes to Health and Longevity. Applied Psychology: Health and Well-Being. 3(1), 1-43.

Diener, E. and R.A. Emmons (1984), "The Independence of Positive and Negative Affect," Journal of Personality and Social Psychology, 47, 1105-1117.

Diener, E., E. Sandvik and W. Pavot (1991), Happiness is the Frequency, not the Intensity, of Positive versus Negative Affect, in F. Strack, M. Argyle and N. Schwarz(eds.), Subjective Well Being, pp. 119-139, Oxford UK: Pergamon.

Diener, E., H. Smith and F. Fujita (1995), "The Personality Structure of Affect," Journal of Personality and Social 
Psychology, 69, 130-141.

Doney, P.M. and J.P. Cannon (1997), “An Examination of the Nature of Trust in Buyer-Seller Relationships," Journal of Marketing, 61(2), 35-51.

Emmons, R.A. and E. Diener (1986), "Influence of Impulsivity and Sociability on Positive and Negative Affect," Journal of Personality and Social Psychology, 50, 1211-1215.

Ferrans, C.E. and M.J. Powers (1992), "Psychometric Assessment of the Quality of Life Index," Research in Nursing and Health, 15, 29-38.

Fornell, C. and D. F. Larcker (1981), "Evaluating Structural Equation Models with Unobservable Variables and Measurement Error," Journal of Marketing Research, 18, 39-50.

Grzeskowiak, S., M. J. Sirgy, D. J. Lee, and C. B. Claiborne (2006), "Housing Well Being: Developing and Validating a Measure," Social Indicators Research, 79(3), 503-541.

Hall, D. and J. Stamp (2003), Meaningful Marketing, Dug Hall: New York.

Heady, B., R. Veenhoven, and A. Wearing (1991),"Top-Down Versus Bottom-Up Theories of Subjective Well Being," Social Indicators Research, 24, 81-100. Hennig-Thurau, T., M.F. Langer, and U. Hansen (2001), "Modeling and
Managing Student Loyalty - An Approach Based on the Concept of Relationship Quality," Journal of Services Research, 3(4), 331-344.

House, J.R. (1986), "Social Support and the Quality and Quantity of Life," in Research on Quality of Life, Frank M. Andrews (Ed) Ann Arbor: Institute for Social Research, the University of Michigan, 253-269.

Hudson, J. (2006), "Institutional Trust and Subjective Well Being Across the EU," KYKLOS, 59 (1), 43-62.

Inglehart, R. (1997), Modernization and Postmodernization: Cultural Economic and Political Change in 41 Societies, Princeton, NJ: Princeton University Press.

Inglehart, R. (1999), "Trust, Well-Being, and Democracy," in Democracy and Trust, M. E. Warren (Ed) Cambridge, UK: Cambridge University Press.

Inglehart, R. and J.R. Rabier (1986), "Aspirations Adapt to Situations-But Why Are the Belgians So Much Happier than the French? A Cross-Cultural Analysis of the Subjective Quality of Life," in Research on Quality of Life, F. M. Andrews (Ed), Ann Arbor.

Kamp, I., K. Leidelmeijer, G. Marsman, and A. Hollander (2003), "Urban 
Environment Quality and Human Well-Being Towards a Conceptual Framework and Demarcation of Concepts: a Literature Study," Landscape and Urban Planning, 65(1), 5-18.

Kelly, J. M. (2003), "Citizen Satisfaction and Administrative Performance Measure, Is There Really a Link?" Urban Affairs Review, 38(6), 855-866.

Kozma, A. (1997), "Stability in Components and Predictors of Subjective Well Being," in Developments in Quality of Life Studies in Marketing, $\mathrm{H}$. L.Meadow, D. Rahtz, and A.C. Samli (Eds), Blacksburg, Virginia: International Society for Quality of Life Studies, 50.

Kotler, P., S. Jutasripitak, and S. Maesincee (1997), The Marketing of Nations, The Free Press, New York, NY.

Lane, C. (1998), "Theories and Issues in the Study of Trust", in C. Lane and R. Bachman (Eds). Trust Within and Between Organizations: Conceptual Issues and Empirical Applications, Oxford University Press: Oxford.

Lee, D.J. and M.J. Sirgy (2004), "Quality-of-Life Marketing: Proposed Antecedents and Consequences," Journal of Macromarketing; 24 (1), 44-58.
Lee, D.J., M.J. Sirgy, V. Larsen, and N.D. Wright (2002), "Developing A Subjective Measure of Consumer Well-Being," Journal of Macromarketing, 22(2), 158-169.

Leelakulthanit, O., R. Day, and R. Walters (1991), "Investigating the Relationship between Marketing and Overall Satisfaction with Life in a Developing Country," Journal of Macromarketing; 11(Spring), 3-23.

Lucas, R. E., E. Diener, and E. Suh (1996), "Discriminant Validity of Well-being Measures," Journal of Personality and Social Psychology, 71, 616-628.

MacKinnon, D.P., G. Warsi, and J.H. Dwyer (1995), "A Simulation Study of Mediated Effect Measures," Multivariate Behavioral Research, 30(1), 41-62.

Mayer, R.C., J.H. Davis, and F.D. Shoorman (1995), "An Integrative Model of Organizational Trust," Academy of Management Review, 20(3), 709-734.

Morgan, R.M. and S.D. Hunt (1994), “The Commitment-Trust Theory of Relationship Marketing," Journal of Marketing, 58(July), 20-38.

North, D.C. (1990), Institutions, Institutional Change, and Economic Performance, New York: Cambridge University Press. 
Paddison, R. (1993), "City marketing, image reconstruction and urban regeneration," Urban Studies, 30(2), 339-350.

Pilcher, J. J. (1998), "Affective and Daily Event Predictors of Life Satisfaction in College Students," Social Indicators Research, 43(3), 291-306.

Plutchick, R. (2003), Emotions and Life: Perspectives from Psychology, Biology, and Evolution, American Psychological Association.

Rahtz, D.R., M. J. Sirgy, and D.J. Lee (2004), "Further Validation and Extension of the Quality-of-Life/ Community-Healthcare Model and Measures," Social Indicators Research, 69(2), 167-198.

Rogerson, R. J. (1999), "Quality of Life and City Competitiveness," Urban Studies, 36(5-6), 969-985.

Sam, D. L. (2001), "Satisfaction with Life among International Students: An Exploratory Study," Social Indicators Research, 53, 315-337.

Schmuck, P., T. Kasser and R. M. Ryan (2000), "Intrinsic and Extrinsic Goals: Their Structure and Relationship to Well-Being in German and U. S. College Students," Social Indicators Research, 50, 225-241.

Selnes, F. and K. G×⿱一𫝀nhaug (2000), "Effects of Supplier Reliability and Benevolence in Business Marketing," Journal of Business Research, 49, 259-271.

Senlier, N., R. Yildiz, and E. D. Aktas (2009), "A Perception Survey for the Evaluation of Urban Quality of Life in Kocaeli and a Comparison of the Life Satisfaction with the European Cities," Social Indicators Research, 94(2), 213-226.

Shapiro, D., B.H. Sheppard, L. Cheraskin (1992), "Business on a Handshake," Negotiation Journal, 8 (October), 365-377.

Sirdeshmukh, D., J. Singh, and B. Sabol, (2002), "Consumer Trust, Value, and Loyalty in Relational Exchange," Journal of Marketing, 66, 15-37.

Sirgy, M.J. (1986), “A Quality of Life Theory Derived from Maslow's Development Perspective: 'Quality' is Related to Progressive Satisfaction of a Hierarchy of Needs, Lower Order and Higher," American Journal of Economics and Sociology, 45(July), 329-432.

Sirgy, M.J. (2001), Handbook of Quality of Life Research, Dordrecht, The Netherlands: Kluwer.

Sirgy, M.J. and D.J. Lee (2006), "Macro Measure of Consumer Well Being: A Critical Analysis and Research Agenda," Journal of Macromarketing, 
26(1), 27-44.

Sirgy, M.J., D. J. Lee, S. Grzeskowiak, J.C. Chebat, J.S. Johar, A. Herman, S. Hassan, I. Hegazi, A. Ekici, D. Webb, C. Su, and J. Montana (2008), “An Extension and Further Validation of a Community-based Consumer Wellbeing Measure," Journal of Macromarketing, 28(3), 243-257.

Sirgy, M.J., D.J. Lee, and D. Rahtz (2006), "Macro Measures of Consumer Well Being (CWB): A Critical Analysis and Research Agenda," Journal of Macromarketing, 26 (1), 27-44.

Sirgy, M.J., D.J. Lee, and D. Rahtz (2008), "Research on Consumer Well Being: Overview of the Field and Introduction to the Special Issue," Journal of Macromarketing, 27 (4), 341-349.

Sirgy, M.J., D. Rahtz, and D.J. Lee (2004), Community Quality of Life Indicators, Kluwer Academic Publishers, Netherlands.

Sirgy, M.J., R. N. Widgery, D. J. Lee, and G.B. Yu (2010), "Developing a Measure of Community Well-Being Based on Perceptions of Impact in Various Life Domains," Social Indicators Research, 96(2), 295-311.

Sirgy, M.J., T. Gao, and R. F. Young (2008), “How Does Resident's Satisfaction with Community Services
Influence Quality of Life (QOL) Outcomes?" Applied Research in Quality of Life, 3 (2), 81-106.

Stimson, R.J., J. Western, P. Mullins, and R. Simpson (1999), “Urban Metabolism as a Framework for Investigation Quality of Life and Sustainable Development in the Brisbane-southeast Queensland Metro Region”. In L.L. Yuan, B. Yuen and C. Low (Eds.), Urban Quality of Life: Critical Issues and Options (pp.143-169). Singapore: Singapore University Press.

Suh, E., E. Diener, and F. Fujita (1996), "Events and Subjective Well Being: Only Recent Events Matter," Journal of Personality and Social Psychology, 70(5), 1091-1102.

Szymanski, D. M. and D. H. Hernand (2001), "Customer Satisfaction: A Meta Analysis of the Empirical Evidence," Journal of the Academy of Marketing Science, 29(1), 16-35.

Tilson, D.J. and D.W. Stacks (1997), "To Know Us is to Love Us: The Public Relations Campaign to Sell a 'Business-Tourist-Friendly' Miami," Public Relations Review, 23, 95-115.

Taifel, H., J.C. Turner (1986), "The Social Identity Theory of Intergroup behavior, In: Worchel S, Austin W, editors. Psychology of Intergroup Relations. 
Second Edition. Chicago: Nelson-Hall; 7-24.

Van Ryzin, G.G., D. Muzzio, S. Immerwahr, L.Gulick, and E. Martinez (2004), "Drivers and Consequences of Citizen Satisfaction: An Application of the ACSI model to New York City," Public Administration Review, 64(3), 331-341.

Veenhoven, R. (1984), Conditions of Happiness, Kluwer Academic, Dordrecht, Boston

Veenhoven, R. (2009), "Well-Being in Nations and Well-Being of Nations," Social Indicators Research, 91(1), 5-21.

Verhoef, P. C., P. H. Franses and J. C. Hoekstra (2002), "The Effect of Relational Constructs on Consumer Referrals and Number of Services Purchased From a Multiservice Provider: Does Age of Relationship Matter?" Journal of the Academy of Marketing Science, 30(3), 202-216.

Vieto, R (2007), How Countries Compete, Harvard Business School Press, Boston MA.

Wish, N.B. (1986), "Are We Measuring the Quality of Life" Well-being Has Subjective Dimensions, As Well As Objective Ones," Journal of Economics and Sociology, 45(1), 93-99.

Yu, G.B. and D.J. Lee (2008), “A Model of
Quality of College Life (QCL) in Korea," Social Indicators Research, 87(2), 269-285.

Yuan, L. L., B. Yuen, and C. Low (1999). Quality of Life in Cities-definition, Approaches and Research. In L. L. Yuan, B. Yuen and C. Low (Eds.), Urban Quality of Life: Critical Issues and Options (pp. 1-13). Singapore: Singapore University Press.

Zucker, L.G.(1986), "Production of trust: Institutional Sources of Economic Structure, 1840-1920", Research in Organizational Behavior, 8, 53-111. 


\section{도시 생활의 질(Quality of City Life) 측정 도구의 개발 : 서울시를 중심으로}

이 동 진*

유 병 희**

\section{국문요약}

도시 생활의 질에 대한 주민들의 인식은 긍정적인 도시 브랜드 이미지 형성에 기여할 뿐 아니라, 도 시에 대한 만족, 신뢰, 충성도 등 도시와의 전반적 관계의 질에도 중요한 영향을 미친다. 도시 생활 의 질이 도시 마케팅에 중요한 요소임에도 불구하고, 기존 측정도구들이 소도시 지역사회 중심의 커 뮤니티 웰빙 측정도구들이어서, 대도시에서의 주관적 도시 생활의 질(Quality of City Life)을 측정 하기 위한 측정도구가 요구되는 실정이다. 본 연구의 목적은 대도시 시민들이 인지하는 도시 생활의 질(Quality of City Life)에 관련된 측정 도구를 개발하여 도시 마케팅의 기초 자료로 활용하는데 있 다. 시민들이 인지하는 도시 생활의 질이란 시민들이 도시에서의 생활을 통해 전반적으로 경험하는 욕구 만족과 행복감의 정도를 의미한다. 본 연구에서는 도시 생활의 질 측정도구를 개발하기 위해 문헌조사와 전문가 심층 인터뷰를 통해 기초문항을 도출하고, 사전 조사를 거쳐 서울시의 25 구에 사 는 시민 507 명을 거주 구역별 할당방식에 의한 설문 조사를 실시하였다. 조사 결과 신뢰도와 개념 타당도가 있는 도시생활의 질 측정문항을 도출하였다.

도시 생활의 질 측정도구는 서울시의 서비스에 대한 만족, 서울시에 대한 신뢰, 시민 자부심 및 구전의향에 긍정적 영향을 미치는 예측 타당도를 가지는 것으로 나타났다.

핵심개념: 도시 생활의 질, 도시 서비스에 대한 만족, 도시에 대한 신뢰, 시민 자부심, 구전 의향

* 연세대학교 경영학과 교수, djlee81@yonsei.ac.kr, 주저자

** 연세대학교 경영학과 박사, bienie81@yonsei.ac.kr, 교신저자

26 한국마케팅저널 제13권 제1호 2011년 4월 